\title{
The rare genus Leptofoenus Smith, 1862 (Hymenoptera: Pteromalidae, Leptofoeninae): new records, and aspects of its distribution
}

\author{
DANIELL R.R. FERNANDES ${ }^{1}$, RICARDO KAWADA ${ }^{2}$ and MARCELO T. TAVARES ${ }^{2}$ \\ ${ }^{1}$ Instituto Nacional de Pesquisas da Amazônia, Coordenação de Biodiversidade, \\ Av. André Araújo, 2936, Aleixo, 69067-375 Manaus, AM, Brazil \\ ${ }^{2}$ Universidade Federal do Espírito Santo, Departamento de Ciências Biológicas, Av. \\ Fernando Ferrari, 514, Goiabeiras, 29075-910 Vitória, ES, Brazil \\ Manuscript received on February 13, 2019; accepted for publication on April 29, 2019
}

\begin{abstract}
How to cite: FERNANDES DRR, KAWADA R AND TAVARES MT. 2019. The rare genus Leptofoenus Smith, 1862 (Hymenoptera: Pteromalidae, Leptofoeninae): new records, and aspects of its distribution. An Acad Bras Cienc 91: e20190153. DOI 10.1590/0001-3765201920190153.
\end{abstract}

\begin{abstract}
Despite being the largest and most remarkable species of Chalcidoidea, species of Leptofoeninae are very rarely collected. Here, we expand the distribution range extension of the Leptofoenus howardi (Ashmead, 1895) for Rondônia and Minas Gerais, Leptofoenus stephanoides (Roman, 1920) for Rondônia, Espírito Santo and São Paulo and Leptofoenus westwoodi (Ashmead, 1895) for Roraima, Amazonas, Rondônia, Bahia, Minas Gerais, Rio de Janeiro and Rio Grande do Sul.
\end{abstract}

Key words: Amazon rainforest, Atlantic rainforest, biology, Brazilian savanna, Brazilian dry forest, Neotropical region.

\section{INTRODUCTION}

Pteromalidae (Hymenoptera: Chalcidoidea) comprises one of the largest families of Chalcidoidea, comprising 639 genera and more than 3500 described species (Noyes 2018). In Brazil, the pteromalid fauna is represented by 65 genera and 156 species, distributed in 18 subfamilies (Costa 2018).

According to Krogmann and Burks (2009), Leptofoeninae is probably one of the least known of all subfamilies of Pteromalidae. They are very rarely collected but morphologically are of special interest because contains some of the largest and most remarkable species of Chalcidoidea (LaSalle and Stage 1985).

Correspondence to: Daniell Rodrigo Rodrigues Fernandes

E-mail: daniellrodrigo@hotmail.com

ORCid: https://orcid.org/0000-0002-2208-6349
Leptofoenus Smith, 1862 is a New World genus and comprises five living species, beside one fossil species described from Early Miocene amber (Engel 2009). According to Costa (2018), four species are recorded from Brazil: L. howardi (Ashmead, 1895), L. peleciniformis Smith, 1862, L. stephanoides (Roman, 1920), and L. westwoodi (Ashmead, 1895).

\section{MATERIALS AND METHODS}

This study was based on material deposited in the following five institutions; names of curators given in parenthesis:

ESALQ - Escola Superior de Agricultura Luiz de Queiroz, Universidade de São Paulo, Piracicaba, São Paulo, Brazil (R. A. Zucchi). 
INPA - Instituto Nacional de Pesquisas da Amazônia, Manaus, Amazonas, Brazil (M. L. Oliveira).

LRRP - APTA Ribeirão Preto, Ribeirão Preto, São Paulo, Brazil (N. W. Perioto).

UFES - Universidade Federal do Espírito Santo, Vitória, Espírito Santo, Brazil (M. T. Tavares).

UFRJ - Universidade Federal do Rio de Janeiro, Rio de Janeiro, Rio de Janeiro, Brazil (R. F. Monteiro).

The specimens were identified based on the key presented by LaSalle and Stage (1985). Supplementary data in material examined section is given within brackets and new distribution records are marked by asterisk (*).

Observations were carried out using a Leica MZ 9.5 stereomicroscope under fluorescent light source. Photographs were taken using a DSLR Canon T3i camera attached to a Canon MP-E 65 $\mathrm{mm}$ macro lens with a Cognisys ${ }^{\circledR}$ macro rails. The images were captured using Helicon Remote software (version 3.9.5 W), and a series of partially focused digital images were stacked using the Helicon Focus software (Version 6.8.0 Pro) by CHelicon Soft Ltd., 2000 to produce final images with enhanced quality. For a more efficient light diffusion, was used a 3D printed dome modified from Kawada and Buffington (2016).

Species distributions were assembled in a dataset and incorporated into distribution maps. Geographic coordinates of the species records, if not present in labels, were taken from Google Earth software (https://www.google.com/earth/), and the map was generated using SimpleMappr (Shorthouse 2010). Countries and states are listed from north to south, as standardized by Zanella et al. (2000).

\section{TAXONOMY}

Here, we present new distributional records of three species: L. howardi, L. stephanoides and
L. westwoodi from material examined. The other species recorded to Brazil (L. peleciniformis) has been recorded from Amazonas and Rondônia territory (Guaporé) by LaSalle and Stage (1985) and Noyes (2018) but it was not examined in the material.

Pteromalidae Dalman, 1820

Leptofoeninae Handlirsch, 1925

Leptofoenus Smith, 1862

Leptofoenus howardi (Ashmead, 1895)

(Fig. 1)

Material examined: 1 male and 2 females. BRAZIL, Rondônia, Itapuã do Oeste, Jamari National Forest, Igarapé Preto, 09¹1'16.0" S 6256'57.0” W, 07.x.2014, sweeping, JA Rafael, FF Xavier Filho, RM Vieira \& RH Aquino [1 male, INPA]. Minas Gerais: Marliéria, Parque Estadual Rio Doce (PELD), Tereza 3, 19³7's 42 $34^{\circ}$ 'W, 09-16.xi.2003, Malaise, JCR Fontenelle col. [1 female, UFES-148159]; same data except, Tereza 1, 19-26.x.2000 [1 female, UFES-148160].

Distribution: Surinam, Brazil and Paraguay (LaSalle and Stage 1985).

Distribution in Brazil, by States: Mato Grosso, Rio de Janeiro, Santa Catarina (Noyes 2018), Rondonia* and Minas Gerais* (Fig. 2).

Comments: This species is reported only in South America.

Leptofoenus stephanoides (Roman, 1920)

(Fig. 3)

Material examined: 5 females. BRAZIL. Amazonas: [no other data], [1 female, INPA]. Rondônia: Guajará-Mirim, Parque Estadual Guajará-Mirim, 10³4'25.0”S 6405'20.0”W, Ponto 4, 26.i.1998 [1 female, UFES-0050216]. Espírito Santo: Laranja da Terra, Joatuba, Fazenda/Farm Betzel, 280-430 masl, 1950'25'S 4049'40”W, 05-12.x.2012, Malaise b-3 and b-7, MT Tavares \& eq. col. [2 females, UFES-138165 and 134330]. São Paulo: Jaboticabal, 15.ix.2008, J. Janini col. [1 female, LRRP]. 


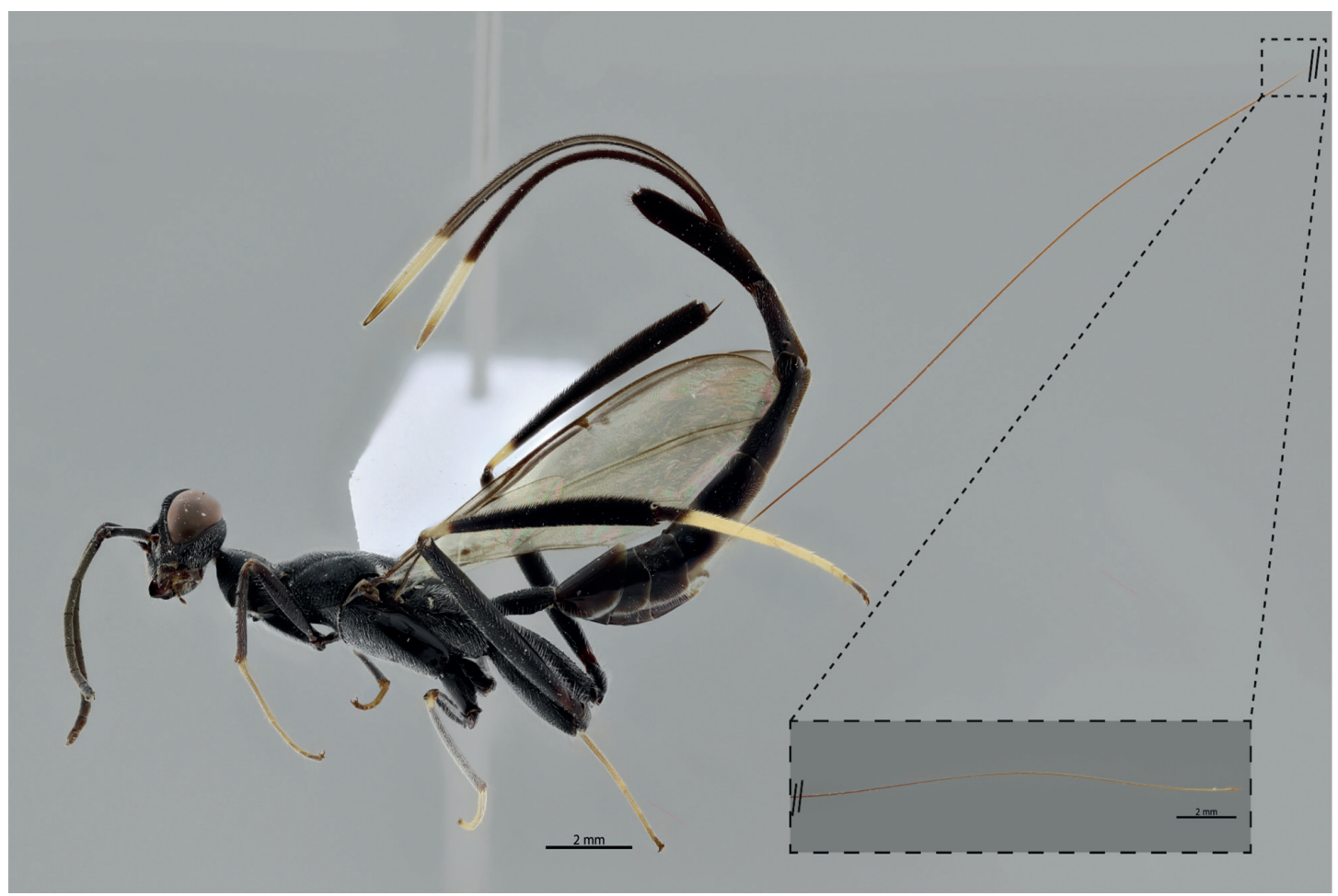

Figure 1 - Leptofoenus howardi (Ashmead, 1895), female habitus.

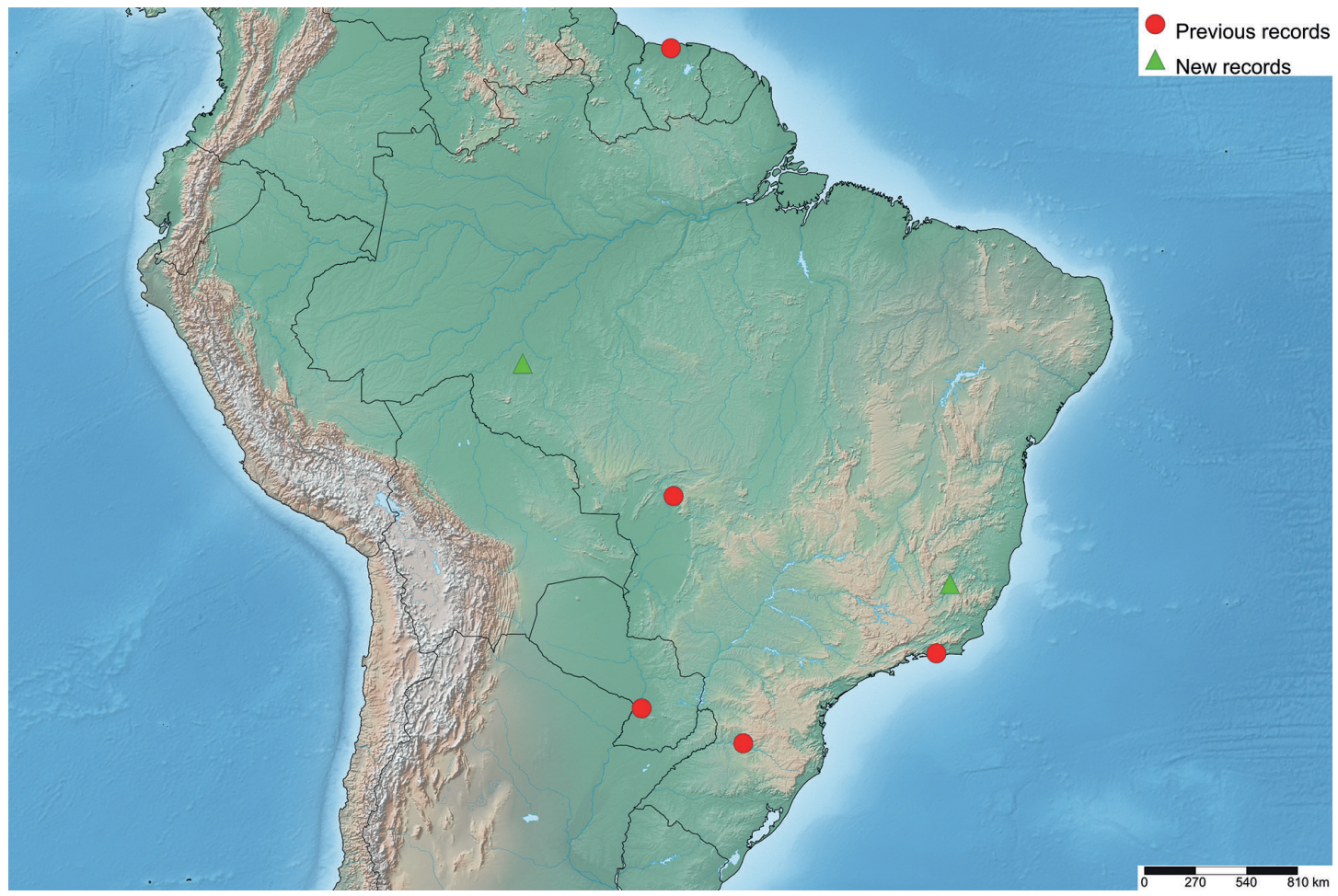

Figure 2 - Distribution records of Leptofoenus howardi (Ashmead, 1895). 


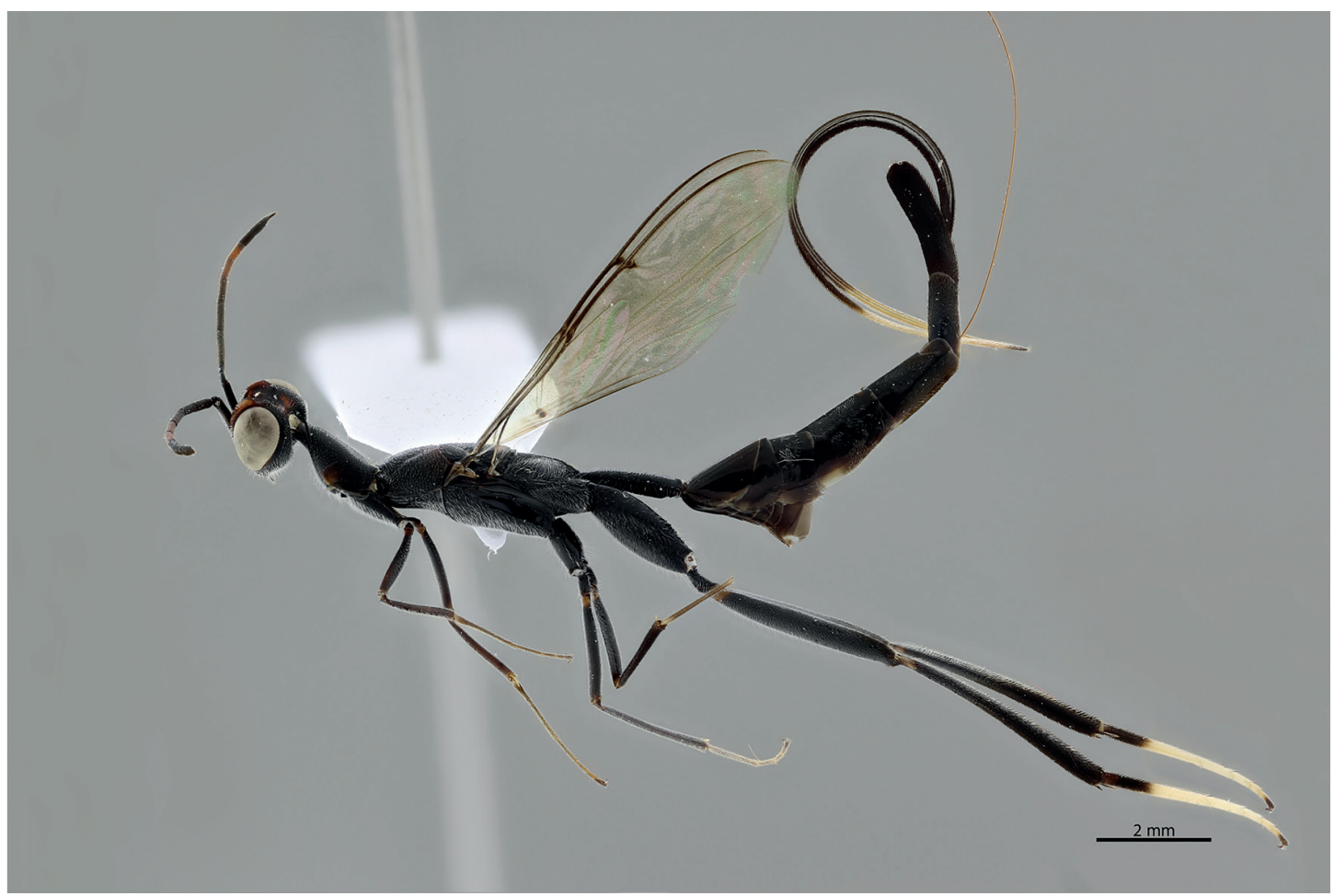

Figure 3 - Leptofoenus stephanoides (Roman, 1920), female habitus.

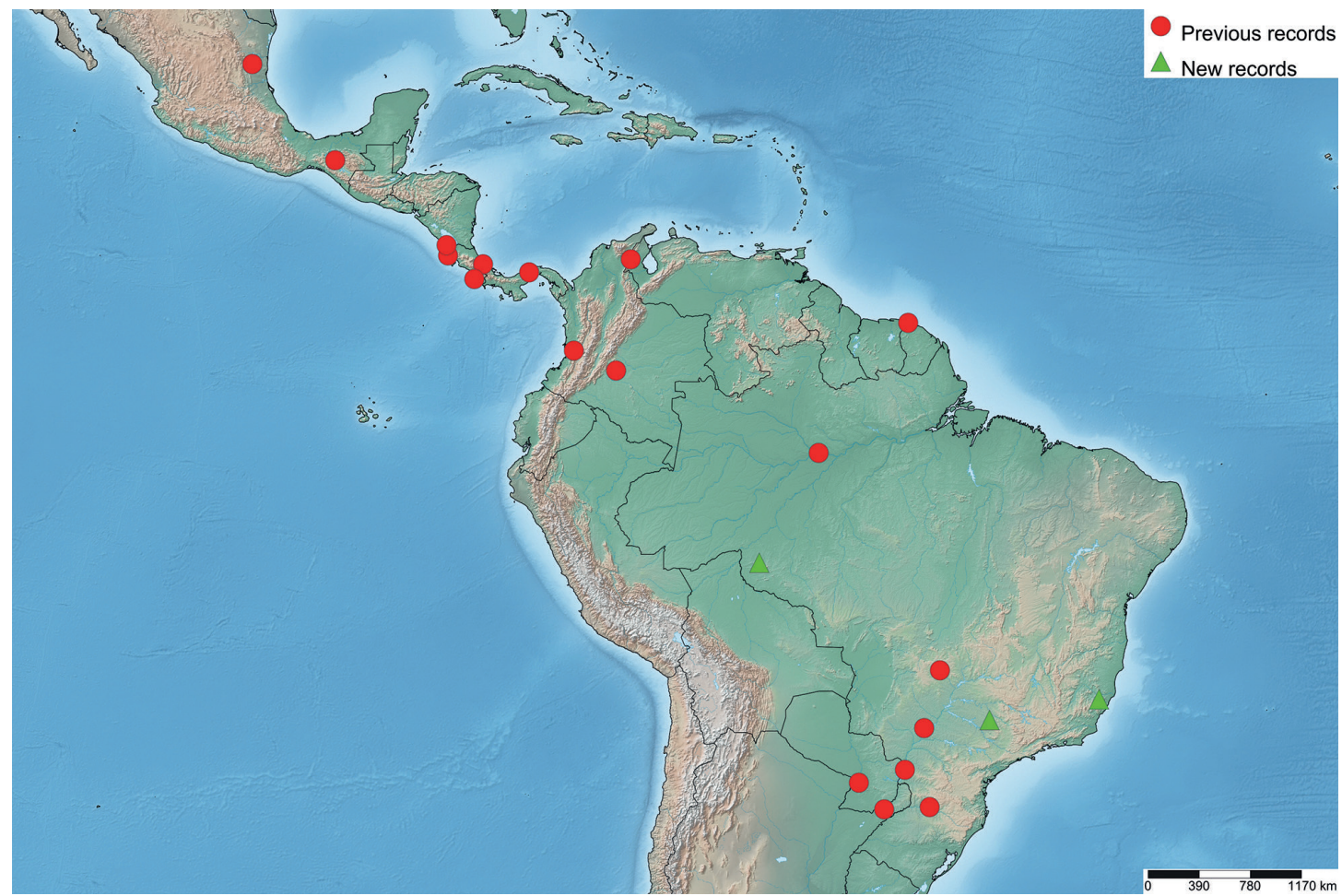

Figure 4 - Distribution records of Leptofoenus stephanoides (Roman, 1920). 
Distribution: Mexico, Costa Rica, Panama, Colombia, Venezuela, French Guiana, Brazil, Paraguay and Argentina (LaSalle and Stage 1985, Ascuntar-Osnas and Torres-Domínguez 2017, Noyes 2018).

Distribution in Brazil, by States: Amazonas, Mato Grosso, Goiás, Paraná, Santa Catarina (LaSalle and Stage 1985, Noyes 2018), Rondônia*, Espírito Santo* and São Paulo* (Fig. 4).

Comments: Is the most widespread species of the genus.

Leptofoenus westwoodi (Ashmead, 1895)

(Fig. 5)

Material examined: 7 females and 2 males. BRAZIL. Roraima: Uraricoera River, Maraca Island, 1-4.iii.1988, Shannon trap, JA Rafael col. [1 female, INPA]. Amazonas: Manaus, Adolpho Ducke Reserve, 255'44.3"5S / 5958'38”W,
Malaise trap, 28.vii-15.x.2016, DA Lima \& NTB Antunes cols. [1 female, INPA]. Pará: Abel Figueiredo, Juca Marhé Farm, 4 $4^{\circ} 52^{\prime}$ S, 48 $31^{\circ}$ 'W, Malaise trap, 10-15.x.2015, J Calhau \& R Kawada cols. [1 female, UFES]. Rondônia: Ouro Preto do Oeste, Malaise trap, 11-13.xi.1984 [1 male, UFES-07383]; Candeias do Jamari, Batallion of Environmental Policy, BR-364, km22, 102masl, 28.i-04.ii.2006, Malaise trap, DF Mugrabi col. [1 female, UFES-149252]. Bahia: Ipiaú, Petrolina Farm, Casca Ranch, 1408'06.0”S 3944'06.0”W, 31.i.2007 [1 female, UFES-0074137]. Minas Gerais: Marliéria, Rio Doce State Park (PELD), Vinhático trail, 1946'S 42³7' $\mathrm{W}, 19-16 . x .2003$, Malaise trap, JCR Fontenelle col. [1 male, UFES148172]. Rio de Janeiro: Rio de Janeiro, Restinga de Jurubatiba National Park, Light trap, forest,

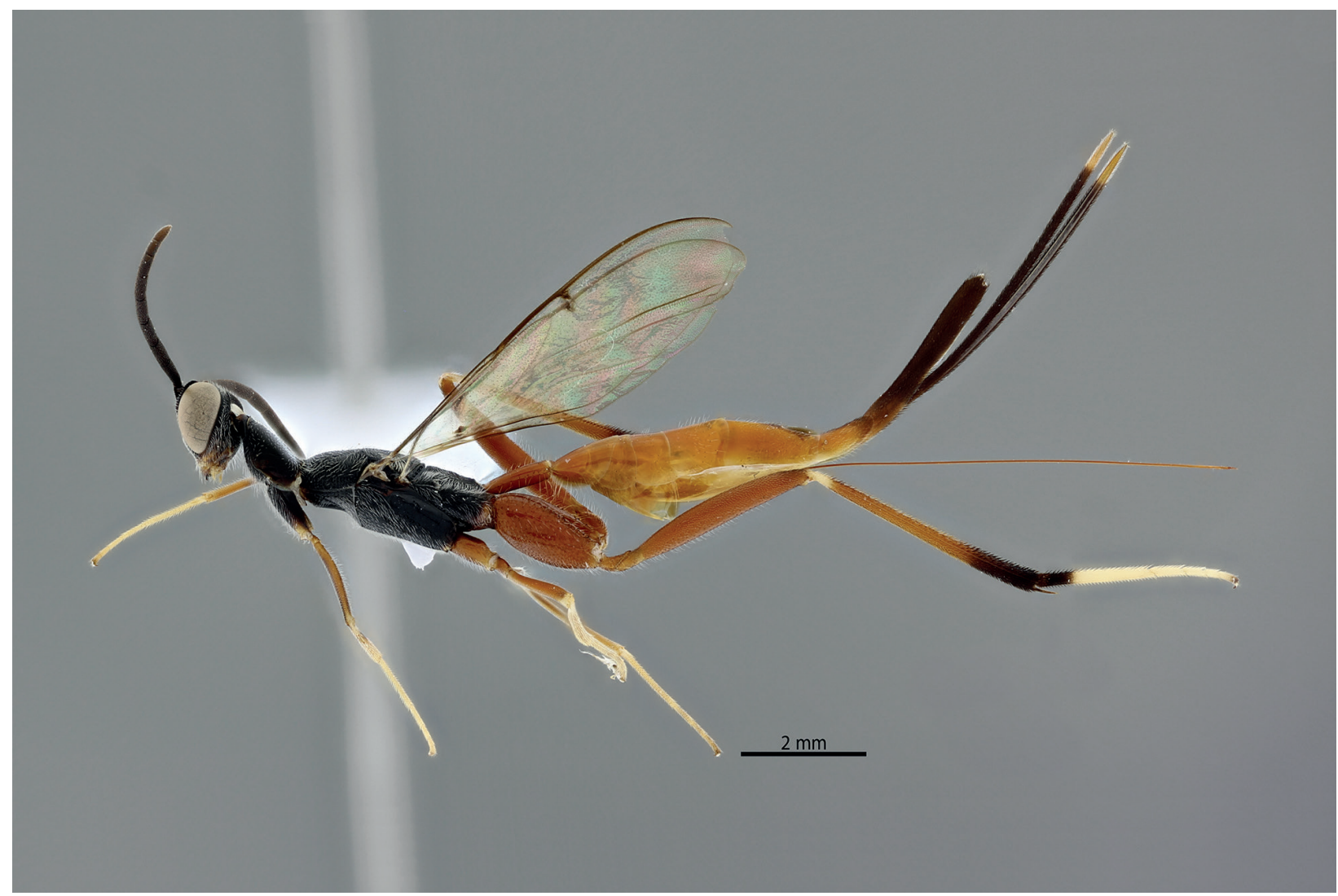

Figure 5 - Leptofoenus westwoodi (Ashmead, 1895), female habitus. 
17.iv.2002. [1 female, UFRJ]; Rio Grande do Sul: Encruzilhada do Sul, on Acacia mearnsii twigs, 15.i.2014, C Azambuja col. [1 female, ESALQ].

Distribution: Panama, Trinidad \& Tobago, Venezuela, Guyana, Peru, Brazil, Bolivia, Paraguay and Argentina (LaSalle and Stage 1985, Engel 2015, Noyes 2018).

Distribution in Brazil, by States: Pará, Mato Grosso, Mato Grosso do Sul (LaSalle and Stage 1985, Shimbori et al. 2017), Roraima*, Amazonas*, Rondônia*, Bahia*, Minas Gerais*, Rio de Janeiro* and Rio Grande do Sul* (Fig. 6).

Comments: About their biology, nothing is known although their morphology suggest that they might attack wood-boring beetles (Engel 2015). Thus, one specimen of $L$. westwoodi (collected in Rio Grande do Sul) was captured in association on branches of Acacia mearnsii De Wild. (Fabaceae). Some species of Cerambycidae (Coleoptera) are pests of $A$. mearnsii in south Brazil (Ono et al. 2014), among them are Oncideres impluviata (Germar, 1842), the most important pest of black wattle in this country. This suggests that $L$. westwoodi probably attack insects on branches. The most common Coleoptera pests in branches are Curculionidae (Scolytinae) and Cerambycidae (Ono et al. 2014). Due to its size it is probable that Leptofoenus is associated with cerambycid and not with scolytine. In the sample area there was a considerable infestation of Oncideres sp. and it is probable that this could be a potential host. However, further studies should be carried out to prove this fact.

\section{DISCUSSION}

The species of the genus are exclusively present in the New Word, between the latitudes $36^{\circ}$ North and $32^{\circ}$ South (Fig. 7). Leptofoenus rufus LaSalle

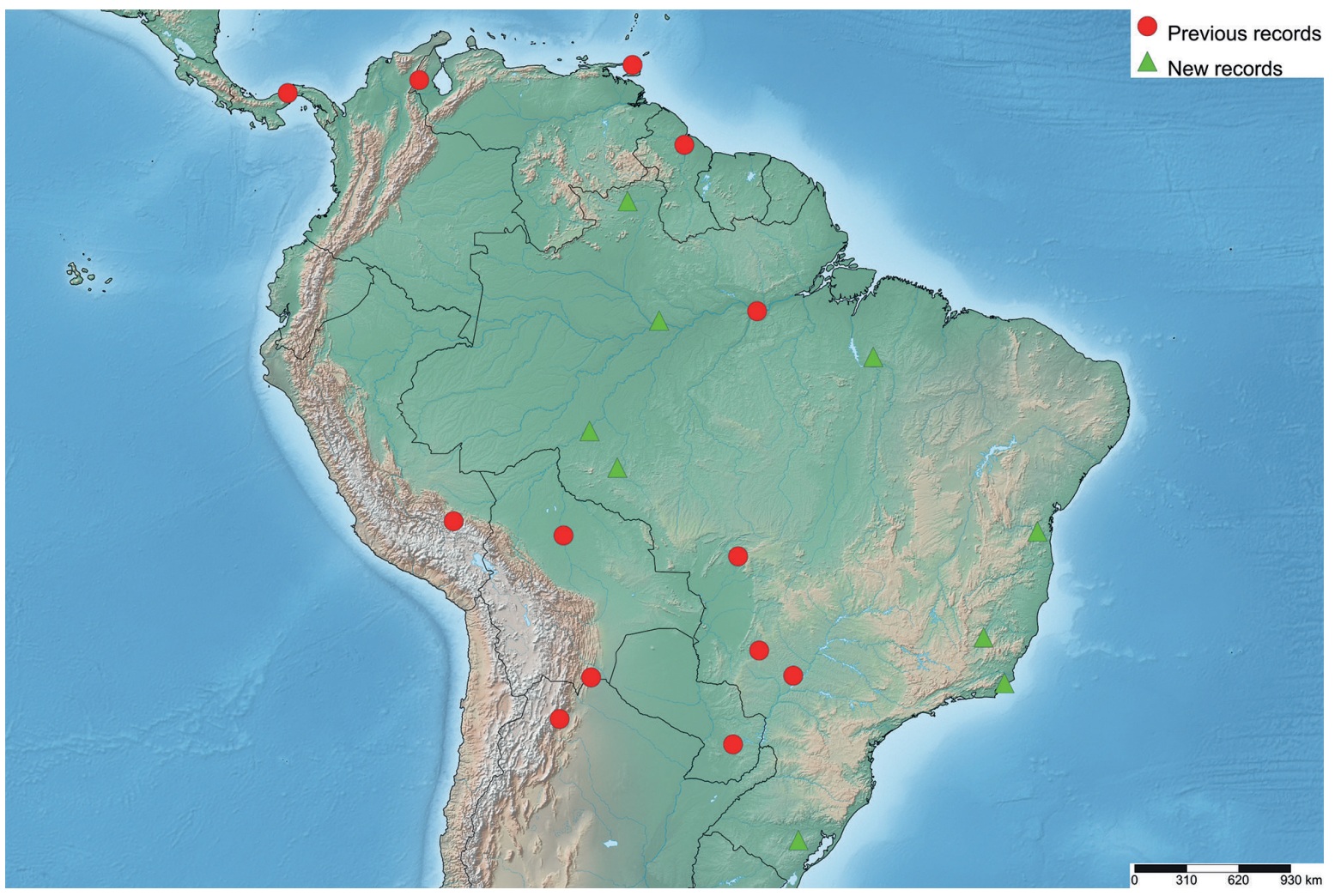

Figure 6 - Distribution records of Leptofoenus westwoodi (Ashmead, 1895). 
$\&$ Stage, 1985 reaches the higher north latitude in distribution. It seems to be confined between south of Nearctic (USA: Arizona and California) and north of Neotropical(Mexico: Oaxaca), and presents the smallest geographic distribution (LaSalle and Stage 1985). Leptofoenus stephanoides has the largest geographic distribution, from latitude of $24^{\circ}$ North to $27^{\circ}$ South. The remaining species are almost restricted to and widespread into South America, except L. peleciniformis which has been recorded in Costa Rica and Panama.

A remarkable distribution aspect is the absence of species on drier and with open vegetation areas, as Cerrado and Caatinga (in Brazil), Guianan savanna and Los Llanos (North of South America), and others. According to the data of examined specimens (present paper and literature), the species are restricted to woody areas, as Atlantic Forest, Amazonian Forest and Riparian Forest.

\section{ACKNOWLEDGMENTS}

We thank Coordenação de Aperfeiçoamento de Pessoal de Nível Superior (CAPES)/ Programa Nacional de Pós Doutorado (PNPD) for postdoctoral fellowship of the first author; Fundação de Amparo à Pesquisa do Estado do Amazonas (FAPEAM) Edital No 030/2013 - Universal Amazonas (process $n^{\circ}$ 062.00770/2015); Rede Bionorte: Biodiversidade de insetos na Amazônia (process $n^{\circ}$ 407627/2013-8) and Fundação de Amparo à Pesquisa e Inovação do Espírito Santo (FAPES) (process $n^{\circ} 67658830 / 2014$ ).

\section{AUTHOR CONTRIBUTIONS}

DRRF, RK and MTT identified the species, prepared the figures and wrote the manuscript.

\section{REFERENCES}

ASCUNTAR-OSNAS O AND TORRES-DOMÍNGUEZ DM. 2017. Leptofoenus stephanoides (Roman 1920)

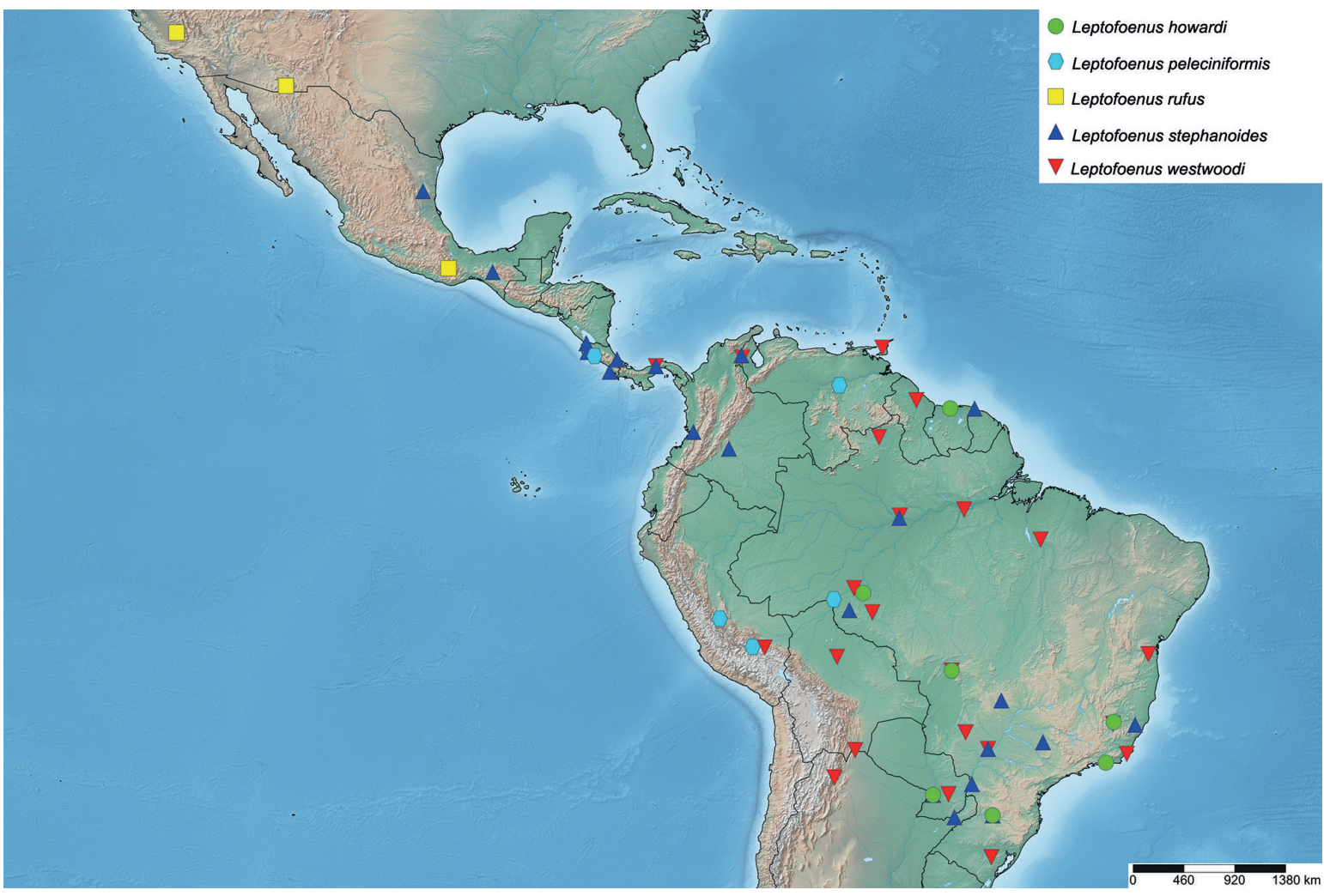

Figure 7 - Distribution records of Leptofoenus Smith, 1862. 
(Pteromalidae: Leptofoeninae): new locality and distribution range extension for Colombia. Acta Zool Mex (n.s.) 33(2): 411-415.

COSTA VA. 2018. Pteromalidae in Catálogo Taxonômico da Fauna do Brasil. PNUD. Disponível em: $<$ http://fauna.jbrj. gov.br/fauna/faunadobrasil/1054>. Acesso 07 Ago. 2018.

ENGEL MS. 2009. The first fossil leptofoenine wasp (Hymenoptera, Pteromalidae): A new species of Leptofoenus in Miocene amber from the Dominican Republic. Zookeys 13: 57-66.

ENGEL MS. 2015. First record of the parasitoid wasp Leptofoenus westwoodi (Ashmead) from Paraguay (Hymenoptera: Pteromalidae). Entomol Mon Mag 151: 55-56.

KAWADA R AND BUFFINGTON ML. 2016. A scalable and modular dome illumination system for scientific microaphy on a budget. PLoS ONE 11(5): 1-20.

KROGMANN L AND BURKS RA. 2009. Doddifoenus wallacei, a new giant parasitoid wasp of the subfamily Leptofoeninae (Chalcidoidea: Pteromalidae), with a description of its mesosomal skeletal anatomy and a molecular characterization. Zootaxa 2194: 21-36.
LASALLE J AND STAGE GI. 1985. The chalcidoid genus Leptofoenus (Hymenoptera: Pteromalidae). Syst Entomol 10: 285-298.

NOYES JS. 2018. Universal Chalcidoidea Database. World Wide Web electronic publication. http://www.nhm.ac.uk/ chalcidoids. Access on: 07 Aug. 2018

ONO MA, FERREIRA ENL AND GODOY WAC. 2014. Black wattle insect pest currently in Brazil. Glo Adv Res J Agric Sci 3(12): 409-414.

SHIMBORI EM, ONODY HC, FERNANDES DRR, SILVESTRE R, TAVARES MT AND PENTEADO-DIAS AM. 2017. Hymenoptera "Parasitica" in the state of Mato Grosso do Sul, Brazil. Iheringia, Sér Zool 107(Suppl.): e2017121.

SHORTHOUSE DP. 2010. SimpleMappr, an online tool to produce publication-quality point maps. http://www. simplemappr.net [accessed 22 April 2017].

ZANELLA FCV, OLIVEIRA ML AND GAGLIANONE MC. 2000. Standardizing lists of locality data for examined specimens in systematic and biogeography studies of new world taxa. Biogeographica 76: 145-160. 